\title{
molecules
}

ISSN 1420-3049

www.mdpi.com/journal/molecules

Article

\section{Chemo-Enzymatic Synthesis of Silybin and 2,3-Dehydrosilybin Dimers}

\author{
Eva Vavř́́ková ${ }^{1}$, Jan Vacek ${ }^{2}$, Kateřina Valentová ${ }^{1,2}$, Petr Marhol $^{1}$, Jitka Ulrichová ${ }^{2}$, \\ Marek Kuzma ${ }^{1}$ and Vladimír Křen ${ }^{1, *}$
}

1 Institute of Microbiology, Academy of Sciences of the Czech Republic, Vídeňská 1083, CZ-142 20 Prague 4, Czech Republic; E-Mails: vavrikova@biomed.cas.cz (E.V.); kata.valentova@email.cz (K.V.); rtepm@seznam.cz (P.M.); kuzma@biomed.cas.cz (M.K.)

2 Department of Medical Chemistry and Biochemistry, Faculty of Medicine and Dentistry, Palacký University, Hněvotínská 3, CZ-775 15 Olomouc, Czech Republic;

E-Mails: jan.vacek@upol.cz (J.V.); jitka.ulrichova@upol.cz(J.U.)

* Author to whom correspondence should be addressed; E-Mail: kren@biomed.cas.cz; Tel.: +420-296-442-510; Fax: +420-296-442-509.

Received: 12 February 2014; in revised form: 24 March 2014 / Accepted: 27 March 2014 / Published: 2 April 2014

\begin{abstract}
Divalent or multivalent molecules often show enhanced biological activity relative to the simple monomeric units. Here we present enzymatically and chemically prepared dimers of the flavonolignans silybin and 2,3-dehydrosilybin. Their electrochemical behavior was studied by in situ and ex situ square wave voltammetry. The oxidation of monomers and dimers was similar, but adsorption onto the electrode and cell surfaces was different. A 1,1-diphenyl-2-picrylhydrazyl (DPPH) and an inhibition of microsomal lipoperoxidation assay were performed with same trend of results for silybin and 2,3-dehydrosilybin dimers. Silybin dimer showed better activity than the monomer, while on the contrary 2,3-dehydrosilybin dimer presented weaker antioxidant/antilipoperoxidant activity than its monomer. Cytotoxicity was evaluated on human umbilical vein endothelial cells, normal human adult keratinocytes, mouse fibroblasts (BALB/c 3T3) and human liver hepatocellular carcinoma cell line (HepG2). Silybin dimer was more cytotoxic than the parent compound and in the case of 2,3-dehydrosilybin its dimer showed weaker cytotoxicity than the monomer.
\end{abstract}


Keywords: flavonolignan; silybin; silibinin; dimerization; electrochemistry; antioxidant; microsomal lipid peroxidation; HUVEC; cytotoxicity

\section{Introduction}

The flavonolignan silybin (1), an antioxidant and hepatoprotectant, is a major bioactive component of the extract from the milk thistle [Silybum marianum (L.) Gaertn. (Asteraceae)] denoted as silymarin [1]. Silybin occurs in silymarin as an approximately equimolar mixture of two diastereoisomers: silybin A (1a) and silybin B (1b) (Figure 1) [2]. 2,3-Dehydrosilybin (6) occurs in silymarin in minor amounts (also as a mixture of enantiomers) presumably resulting from spontaneous oxidation of silybin [3], and it has significantly higher anticancer $[4,5]$ and antioxidant $[6,7]$ activity than silybin.

Figure 1. Silybin A (1a) and silybin B (1b).

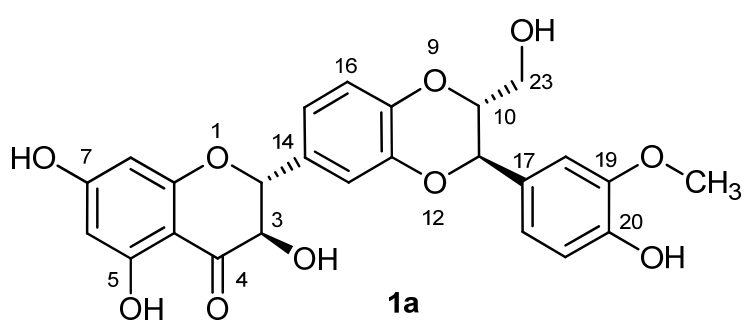<smiles>COc1cc([C@H]2Oc3cc([C@@H]4Oc5cc(O)cc(O)c5C(=O)[C@H]4O)ccc3OC2CO)ccc1O</smiles>

Silybin and its congeners, being effective chemoprotectants, have been used for a diverse range of semisynthetic modifications, both chemical and enzymatic. Enzymatic methods are more suitable than chemical ones due to the sensitivity of these flavonoids to oxidation and extreme $\mathrm{pH}$.

Acylation at position C-23, which does not participate in the antioxidant activity of silybin $[7,8]$, has been accomplished both with chemical [9] and enzymatic [10,11] methods and produced new antiviral and antitumor compounds. Enzymatic acylation/deacylation at the C-23 OH also enabled the first diastereomeric separation at the preparatory scale [12]. On the other hand, modification (e.g., methylation) of C-7 $\mathrm{OH}$, bearing a pro-oxidant potential, significantly improves the antiradical activity of silybin [8].

Silybin has already been covalently conjugated with other drugs, leading to hybrid or co-drug molecules. This was recently exemplified by the preparation of a tacrine-silybin co-drug aiming to lower the hepatotoxicity of tacrine while maintaining its acetylcholinesterase inhibitory effects that are used in the treatment of Alzheimer's disease [13]. Silybin was also linked at C-23 by a phosphodiesteric moiety to various molecules aiming to improve its biological properties [14].

Silybin dimerization has also been achieved: the first oxidative dimerization of partially protected silybin with laccase yielded C-C and C-O dimers [15]. This study was focused on describing the mechanism of oxidative attack on silybin. Later, Theodosiou et al. [11] detected (only by MS) silybin diester dimers linked with dicarboxylic acids to the $23-\mathrm{OH}$ as byproducts of the synthesis of silybin acylated derivatives using lipase-catalyzed esterification. Both of the above studies were performed with natural silybin (1), i.e., an equimolar mixture of silybin A (1a) and B (1b). Using this mixture would not cause a problem in the antioxidant studies, as we have demonstrated that both $\mathbf{1 a}$ and $\mathbf{1 b}$ 
behave in a very similar way towards radical and/or oxidative attack in an isotropic milieu [16]. Nevertheless, interaction with biological systems involves interactions with the 3D structures and here the stereochemistry of the ligands is of the utmost importance. Dimerization of the diastereomeric silybin mixture could lead in theory to three compounds (AA, BB, AB), however, their proportions are rather unpredictable as the lipases typically display stereoselectivity [12] towards $\mathbf{1 a}$ and $\mathbf{1 b}$, and the MS analysis used [11] could not deconvolute the mixture. A typical example of the differing biological activity of $\mathbf{1 a}$ and $\mathbf{1 b}$ is the fact that silybin B (1b) interacts with estrogen receptors, whereas silybin A (1a) is devoid of this activity [17].

Divalent or multivalent molecules often exhibit enhanced biological activity relative to the simple monovalent units [18]. It is not only the multivalency effect that modifies their biological activity (multi-ligand binding) but also their pharmacokinetic parameters, as shown recently in artemisinin dimers used as antimalarial drugs [19]. Sometimes an entirely new biological entity is created by dimerization, e.g., the oligomerization of ergot alkaloids lead to an entirely new antiplasmodial activity [20]. The dimerization of flavonoids, aiming at the preparation of more effective P-glycoprotein inhibitors, has been accomplished by the synthesis of apigenin homodimers linked with polyethylene glycol spacers [21]. This study also demonstrated that the length of the spacer is a critical parameter for the binding of dimers to the target protein(s).

We have decided to prepare defined dimers of silybin and 2,3-dehydrosilybin, including heterodimers using both the diester enzyme-catalyzed concept [22] and the diether (chemical) approach. The basic properties of these new compounds were determined by using antioxidant, electrochemical and toxicological assays to enable their further application in more complex biological studies.

\section{Results and Discussion}

\subsection{Synthesis of Dimers}

Lipase-mediated synthesis is a preferable and very effective method for the selective acylation of primary hydroxyl groups in non-aqueous media [23]. We used the divinyl esters of dicarboxylic acids as donors due to the fact that lipase-catalyzed reaction is faster and the reaction equilibrium is more shifted in favor of transesterification than in the reactions with free acids. Here we used Novozym 435-a lipase B from Candida antarctica immobilized on an acrylic resin, taking advantage of its specific selectivity and straightforward handling. Reactions were performed in dry acetonitrile, in which silybin was completely soluble (ca $12 \mathrm{~g} / \mathrm{L}$ ). In the case of enzymatic reactions silybin is typically not completely dissolved at the start of the reaction but it dissolves as the reactions progress.

The lipase-catalyzed acylation of the primary group of silybin A (1a) and B (1b) was used for preparation of the C-23 derivatives of symmetric dimers of silybin 3 and $\mathbf{4}$ (Scheme 1).

The preparation of the $\mathrm{C}-23$ derivatives of silybin symmetric dimers $\mathbf{3}$ and $\mathbf{4}$ involves a lipase-catalyzed acylation of the primary hydroxyl group of silybin (Scheme 1). The ratio of the stoichiometric coefficients of the reactants silybin and divinylester of dodecandioic acid was 2.7:1. Dodecanedioic acid was converted to its divinyl ester in the presence of vinyl acetate and a catalytic amount of mercury(II) acetate according to [24]. The synthesis of asymmetric dimer 5 was comprised of two 
steps (Scheme 1). First, the synthesis of the activated acyl donor (12-vinyl dodecandioate-23-O-silybin B, 2b) was accomplished by lipase-mediated esterification of the C-23 of $\mathbf{1 a}$.

Scheme 1. Lipase-catalyzed synthesis of optically pure silybin dimers.

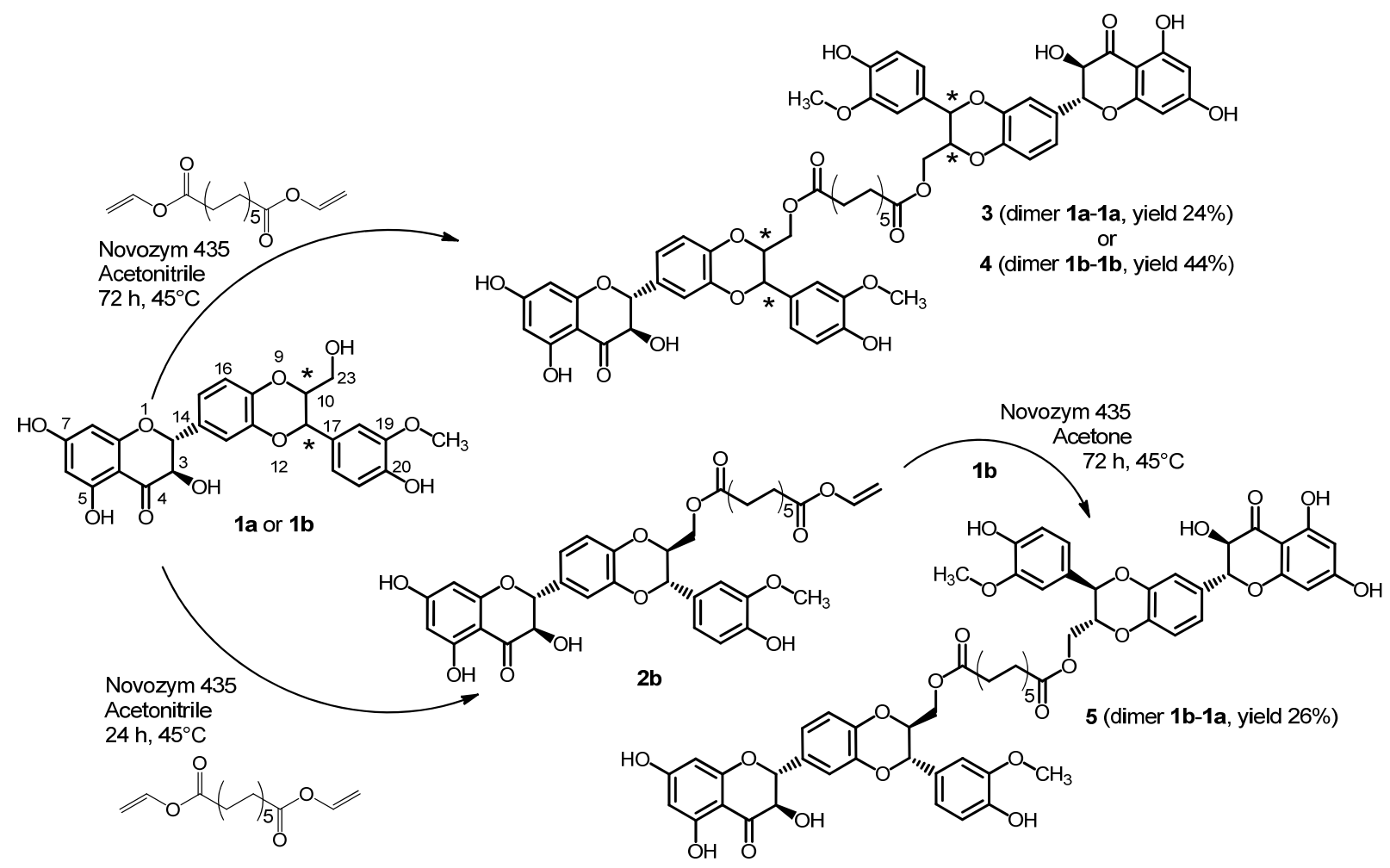

The length of the aliphatic linker between the two units of silybin was optimized. Divinyl esters of succinic (C4), glutaric (C5) and adipic acid (C6) were reacted with silybin under Novozym 435 catalysis but no silybin dimers were formed. The short aliphatic chain did not allow the linkage of two units of silybin, even though monovinyl esters or hydrolyzed esters of silybin were formed. Hence, a divinyl ester of dodecanedioic acid (C12) was compatible with the stereochemistry of sterically demanding molecule of the silybin dimer and the yield of the prepared compounds differs from $24 \%$ to $44 \%$. In the study of Theodosiou et al. [11], silybin dimers with aliphatic chains (C6, C12, C16) were synthesized and detected by HPLC/MS analysis as byproducts during the preparation of silybin acyl esters, however, the yields were very low $(2.9 \%-6.2 \%)$.

The dimer of 2,3-dehydrosilybin (7) was also prepared in the presence of Novozym 435 with a 4:1 ratio of the stoichiometric coefficients of the reactants silybin and divinylester of dodecanedioic acid (Scheme 2). Due to paucity of enantiomerically pure dehydrosilybin the compound 7 was prepared from the enantiomeric mixture.

Chemical synthesis allowed us to prepare entirely new dimers due to the significantly higher reactivity of the hydroxyl group in the position C-7 of silybin in comparison to other hydroxyl groups. Reaction with $p$ - or $m$-xylylene dibromide in the presence of $\mathrm{K}_{2} \mathrm{CO}_{3}$ was used for formation of silybin dimers 8-11 with etheric bridges (Scheme 3). In contrast to the flexible aliphatic linker of dimers 3, 4, 5,7 a xylyl moiety has a rigid structure. 
Scheme 2. Lipase-catalyzed synthesis of 2,3-dehydrosilybin dimer.

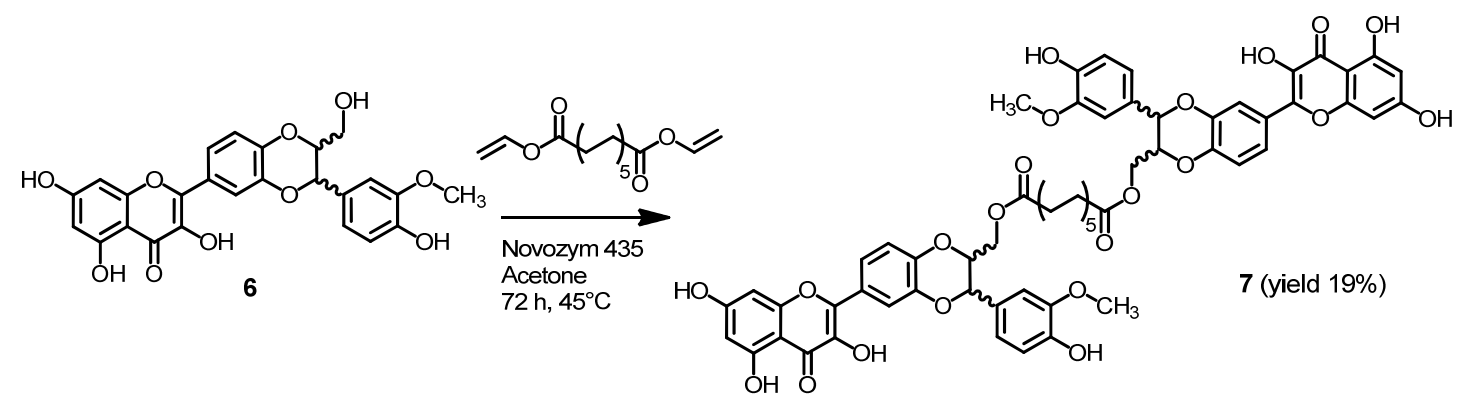

Scheme 3. Synthesis of silybin dimers with ether spacer.
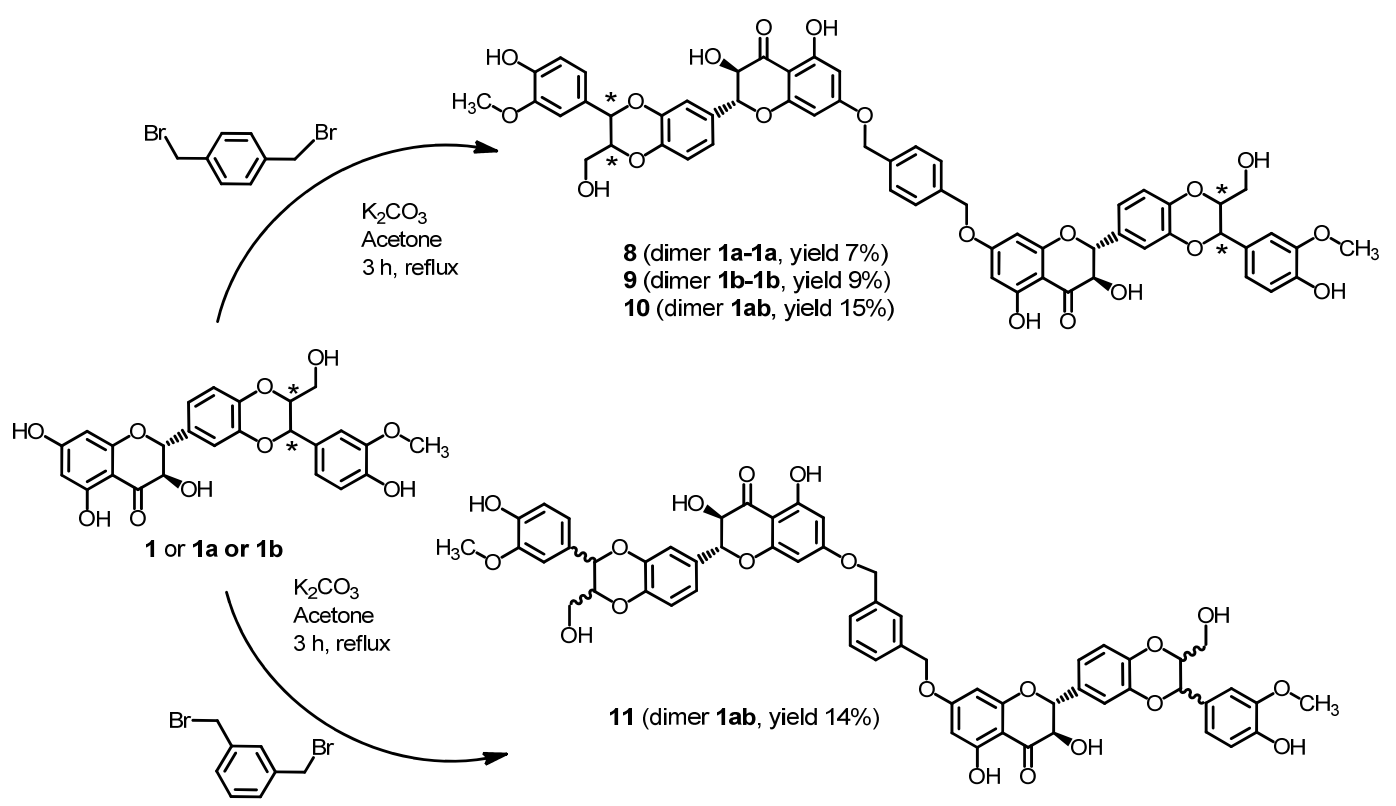

All prepared dimers and monomers 1a, 1b, 6 were tested for electrochemical behavior using SWV and antioxidant activity using DPPH scavenging. Data (not shown) for both types of silybin dimers were comparable with that of the silybin monomers, hence, for following results and discussion silybin A (1a) and the product 3 were chosen (Table 1).

\subsection{Stability of Dimers}

The stability of the dimers in PBS and phosphate buffers (0.2 M, pH 7.4) was determined by HPLC after $24 \mathrm{~h}$. In all cases, no decomposition of the ester or ether bonds was observed (data not shown). However, during longer incubation signs of instability (decomposition) were observed in compounds 4 and $\mathbf{5}$ and, therefore, these compounds were not further tested in biological assays.

\subsection{Electrochemistry}

The electrochemical behavior of monomers 1a, 6 and their dimers was studied using SWV under in situ and ex situ (adsorptive transfer) conditions according to the previously published protocol [7]. For 1a and its dimers we can observed two well-developed oxidation peaks at $E_{\mathrm{p} 1} \sim+0.55 \mathrm{~V}$ and $E_{\mathrm{p} 2} \sim+0.87 \mathrm{~V}$ (Figure 2). 
Table 1. Oxidation potentials $\left(E_{\mathrm{p}}\right)$ and DPPH scavenging for monomeric flavonolignans $(\mathbf{1 a}, \mathbf{6})$ and their dimers at $\mathrm{pH}$ 7.4.

\begin{tabular}{|c|c|c|c|c|}
\hline \multirow[t]{2}{*}{ Compound } & \multicolumn{3}{|c|}{$\begin{array}{c}\text { Oxidation potential [V] * } \\
\text { vs. } \mathrm{Ag} / \mathrm{AgCl} / 3 \mathrm{M} \mathrm{KCl} \\
n=3\end{array}$} & \multirow{2}{*}{$\begin{array}{c}\text { DPPH } \\
{[\% \text { of inhibition] } * *} \\
n=4 \\
33 \mu \mathrm{M}\end{array}$} \\
\hline & $E \mathbf{p}_{3}$ & $E \mathbf{p}_{1}$ & $E \mathbf{p}_{2}$ & \\
\hline $1 \mathbf{a}$ & & 0.55 & 0.90 & $6.6 \pm 1.7^{\mathrm{a}}$ \\
\hline 3 & & 0.56 & 0.83 & $7.1 \pm 2.8^{\mathrm{a}}$ \\
\hline 4 & & 0.57 & 0.83 & $9.0 \pm 3.0^{\mathrm{a}}$ \\
\hline 5 & & 0.55 & 0.83 & $7.0 \pm 2.9^{\mathrm{a}}$ \\
\hline 6 & 0.37 & 0.54 & 0.92 & $82.9 \pm 0.2^{b}$ \\
\hline 7 & 0.36 & 0.57 & 0.99 & $33.4 \pm 3.1^{\mathrm{c}}$ \\
\hline 8 & & 0.56 & 0.81 & $8.5 \pm 3.7^{\mathrm{a}}$ \\
\hline 9 & & 0.57 & 0.83 & $8.9 \pm 4.0^{\mathrm{a}}$ \\
\hline 10 & & 0.56 & 0.80 & $8.1 \pm 3.4^{\mathrm{a}}$ \\
\hline 11 & & 0.52 & 0.87 & $10.7 \pm 3.1^{\mathrm{a}}$ \\
\hline
\end{tabular}

* The values of oxidation potentials Ep were estimated by SWV. The same values can be observed by CV with a difference of $\pm 0.05 \mathrm{~V}$. $* *$ DPPH scavenging is expressed as absorbance change caused by $33 \mu \mathrm{M}$ test compound - the higher the value, the better the scavenger. Values marked with the same letter are not significantly different $(p<0.05) . E_{\mathrm{p} 1} \sim+0.55 \mathrm{~V}$ can be ascribed to oxidation of C-20 OH; $E_{\mathrm{p} 2} \sim+0.87 \mathrm{~V}$ relates to oxidation of resorcinol moiety (ring A), probably C-5 OH; $E_{\mathrm{p} 3} \sim+0.37 \mathrm{~V}$ can be ascribed to oxidation of $\mathrm{C}-3 \mathrm{OH}(6,7)$.

Figure 2. In situ (A) and ex situ (B) SW voltammograms of flavonolignans 1a, 3, 6, and $\mathbf{7}$. Non-adsorbing species in panel (B), i.e., flavonolignans $\mathbf{3}$ and 7, providing the background very similar to "Electrolyte" in panel (A).

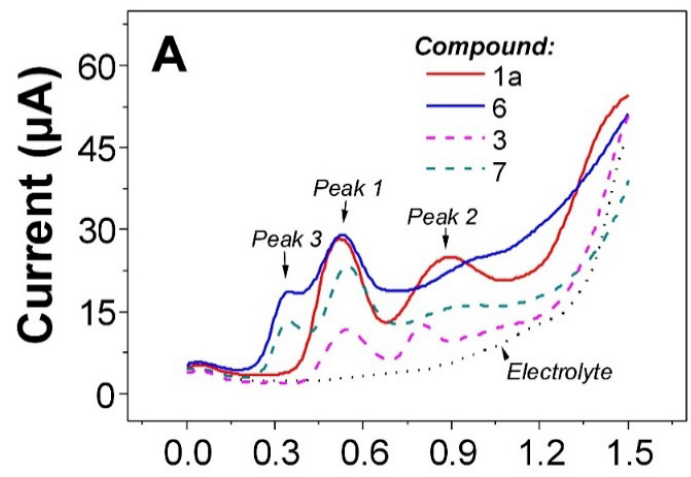

Potential (V)

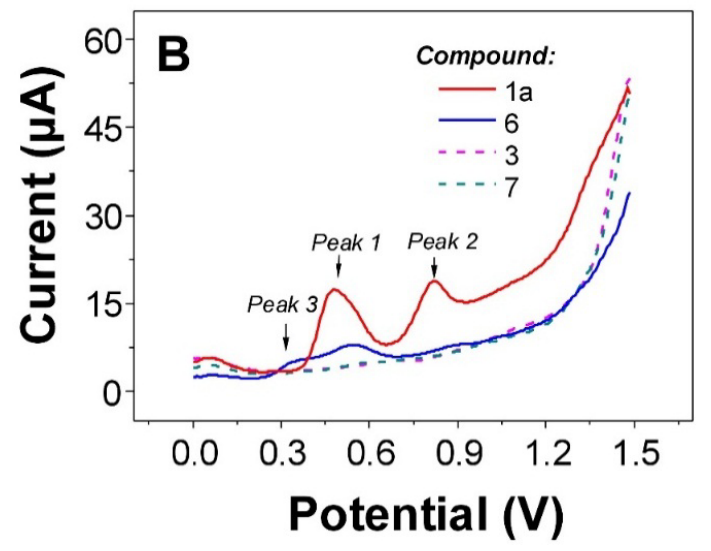


The first peak can be ascribed to oxidation of C-20 hydroxyl group at ring E. Second oxidation step is connected to the oxidation of resorcinol moiety (ring A), most probably C-5 hydroxyl group is involved in the anodic reaction [7,25,26]. Besides above-mentioned, the oxidation of C-3 hydroxyl group (ring C) in 6 and 7 was found at less positive potential, $E_{\mathrm{p} 3} \sim+0.37 \mathrm{~V}$. The peaks occurred at less positive potentials indicate better antioxidant activity of attributed molecule part. Practically no difference in the potentials of oxidation between monomers and their respective dimers were observed (Table 1). This indicates that ability of the dimers to donate electron(s) is very similar as for the parent monomers. The reactivity and antioxidant capacity of the compounds investigated can be deduced from the potential of the first oxidation peak (wave) in the first anodic scan, where the antioxidant capacity of the oxidized compounds is negatively associated with their oxidation potential. Thus, the occurrence of peak 3 for $\mathbf{6}$ and $\mathbf{7}$ indicates that both compounds will be better antioxidants than 1a and its dimers. This statement is in good agreement with many of biological studies where facilitation of biological activities and antioxidant capacity improvement was found for dehydroderivatives of flavonolignans in comparison to $\mathbf{1 a}$ and its congeners [1]. In addition to redox properties, the adsorption behavior of $\mathbf{1 a}$ and $\mathbf{6}$ was also studied and compared to the dimeric forms. It is well known that monomeric flavonolignans are strongly adsorbed onto electrodes at open circuit potential [7,27]. However, the adsorption of dimer $\mathbf{3}$ and $\mathbf{7}$ was strictly limited and practically impossible under the experimental conditions used ( $c f$. Figure 2A,B). The differences in adsorption behavior were also confirmed by a.c. voltammetry (data not shown). Identical adsorption behavior can also be found for other dimers prepared in this work. All SWV data presented here were consistent with results acquired using cyclic voltammetry at $v=1 \mathrm{~V} \mathrm{~s}^{-1}$ with an $E_{\mathrm{p}}$ difference of $\pm 0.05 \mathrm{~V}$.

\subsection{DPPH Scavenging}

All the compounds except the intermediate 2a were screened for their ability to scavenge a stable model radical, 1,1-diphenyl-2-picrylhydrazyl (DPPH) at $33 \mu \mathrm{M}$ and they all were able to scavenge this radical with various efficiencies (Table 1). Silybin 1a displayed 6.6\% inhibition and values between $7.1 \%$ and $10.7 \%$ were found for its dimers, without significant difference $(p<0.05)$. In contrast, racemic 2,3-dehydrosilybin 6 scavenged 83\% and its respected dimer 7 caused a 33.4\% decrease in absorbance. Based on this screening and on the results from the voltammetry, we have selected representative dimers 3 and 7 and the parent molecules, $1 \mathbf{a}$ and $\mathbf{6}$ for more detailed analyses. The $\mathrm{IC}_{50}$ for DPPH scavenging determined for 1a was $225.4 \pm 9.4 \mu \mathrm{M}$ and a significant $(p<0.05)$ improvement in scavenging activity was noted for the respective dimer 3 with $\mathrm{IC}_{50} 137.1 \pm 7.5 \mu \mathrm{M}$. The most powerful DPPH scavenger was racemic 6, with $\mathrm{IC}_{50} 6.43 \pm 0.30 \mu \mathrm{M}$. After dimerization, a significantly $(p<0.05)$ weaker activity was observed for the dimer 7 ; $\mathrm{IC}_{50} 29.0 \pm 0.7 \mu \mathrm{M}$.

\subsection{Inhibition of Microsomal Lipid Peroxidation}

All the compounds tested were able to inhibit the microsomal lipid peroxidation of rat liver microsomes, induced by tert-butyl hydroperoxide (Figure 3). The $\mathrm{IC}_{50}$ determined for 1a was $53.7 \pm 6.1 \mu \mathrm{M}$, while the antilipoperoxidant activity was improved $(p<0.05)$ for the respective dimer 3 with $\mathrm{IC}_{50} 34.0 \pm 4.3 \mu \mathrm{M}$. The most powerful inhibitor of lipid peroxidation was again monomeric 6 , 
with $\mathrm{IC}_{50} 14.53 \pm 0.73 \mu \mathrm{M}$. After dimerization, a weaker activity was observed for the dimer 7; $\mathrm{IC}_{50}$ $59.2 \pm 5.9 \mu \mathrm{M}(p<0.05)$. The lipid peroxidation data are in very good agreement with the DPPH test.

Figure 3. Effect of silybin and 2,3-dehydrosilybin dimers on inhibition of lipid peroxidation induced by $1 \mathrm{mM}$ tert-butyl hydroperoxide in rat liver microsomes. The concentration of lipid peroxidation products was determined as thiobarbituric acid reactive substances (TBARS) and presented as \%. Data are means \pm SD from three independent experiments performed in triplicate.

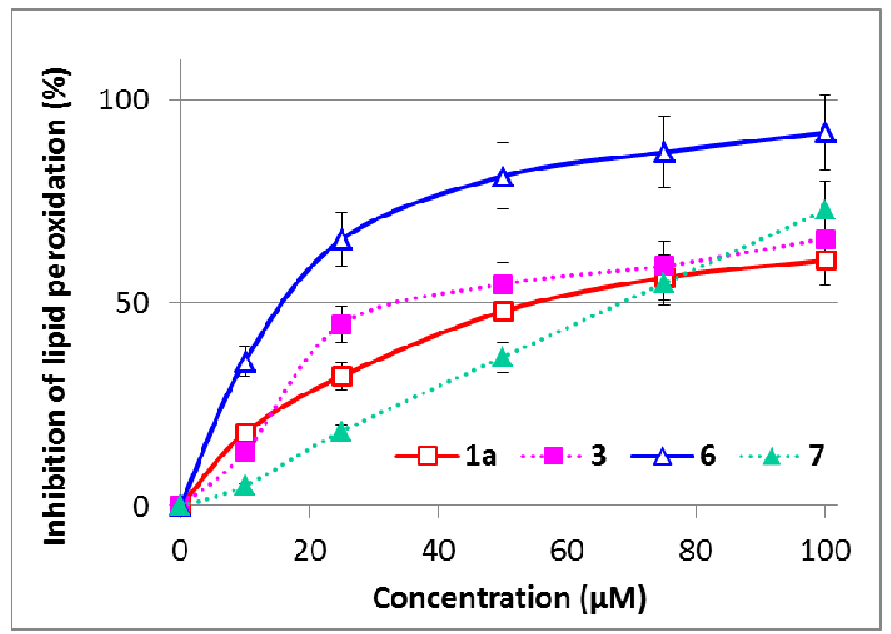

In both DPPH scavenging and microsomal lipid peroxidation tests, the data found for silybin A 1a and 2,3-dehydrosilybin $\mathbf{6}$ are in good agreement with previously published data using a slightly different experimental setting $[6,9,16,28,29]$. With the dimers, we noted an activity for silybin dimer 3 that was approximately 1.6 times that of the parent molecule 1a. This improvement could be attributed simply to an increased number of reactive $\mathrm{OH}$-groups in the resulting molecule. In contrast, the dimerization of 2,3-dehydrosilybin resulted in about a quarter of the activity, which will be discussed in Section 2.6. The electrochemical results indicated that the redox behavior of monomeric and dimeric molecules is quite similar but the interaction (adsorption) ability of the dimers is different. So the explanation of the diversity in the DPPH scavenging and inhibition of lipid peroxidation of the tested flavonolignans will be probably based on their different intra- and inter-molecular interaction mode. This idea is supported by the fact that the oxidation mechanism (electron transfer ability) is practically the same for the monomeric and dimeric state of the compounds investigated.

To the best of our knowledge, no similar comparison has been performed to date. The silybin dimers prepared previously were not tested for biological activity [11,15]. No dimer of 2,3-dehydrosilybin has been prepared so far. Analogous dimers were prepared from ascorbic acid (and dehydroascorbic acid) but only the physico-chemical properties of the dimers were described [22]. Recently, a natural flavan-3-ol dimer was isolated from green tea from Camellia taliensis having DPPH- and $\mathrm{ABTS}^{+}$-scavenging activities superior to all other compounds from the tea, but unfortunately without testing the parent monomer [30]. Natural epicatechin dimer (procyanidin B2) exhibited, when the results were expressed based on a unit molar concentration of epicatechin, comparable DPPH and superoxide radical scavenging activities [31]. On the other hand, various dimers were identified as products of the reaction of various (poly)phenolics with DPPH [32-34]. 
Figure 4. Effect of studied compounds on (A) human umbilical vein endothelial cells; (B) human normal adult keratinocytes; (C) mouse BALB/c fibroblasts and (D) HepG2 cells. The cells, grown to near confluence, were incubated with the tested compounds for $24 \mathrm{~h}$ and their viability was then assessed by MTT test. The results are presented as mean \pm SD from three independent experiments performed in triplicate.
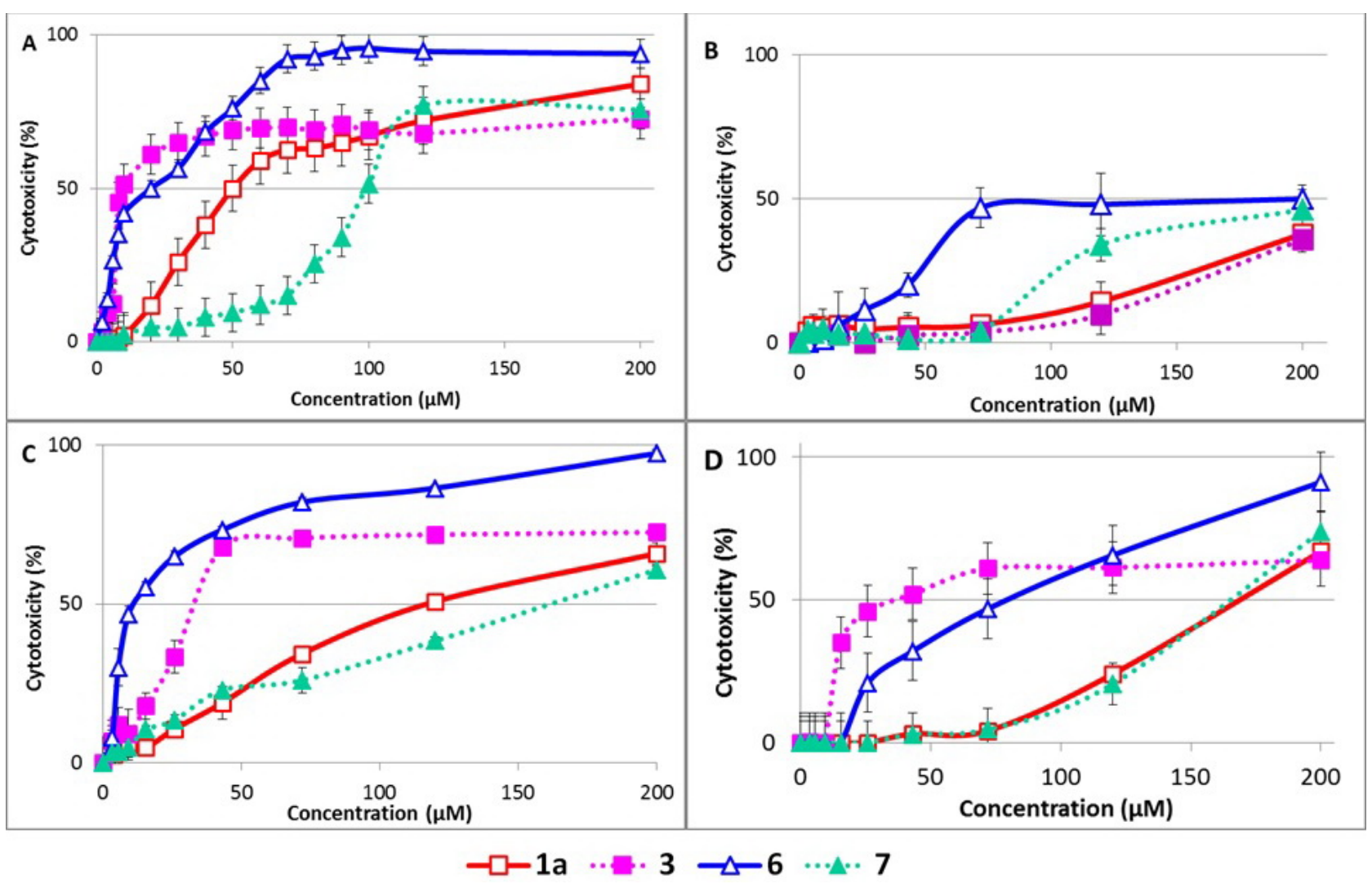

\subsection{Cytotoxicity}

The effect of the studied flavonolignans on cell cultures was evaluated in four types of cells. Two of them (HUVEC and NAK) are primary dividing cells with limited passage possibilities; HUVEC are vascular cells [35] and NAK are skin cells [36]. BALB/c 3T3 fibroblasts are an immortalized non-transformed cell line and HepG2 transformed hepatoma epithelial cells [37]. HUVEC were the most sensitive to the tested compounds and NAK were the most resistant, 50\% cytotoxicity was not achieved for up to $200 \mu \mathrm{M}$ of all the compounds tested in NAK cells (Figure 4). In all other cells used, the same trend can be observed. With 1a, the parent compound displayed quite a low cytotoxicity ( $\mathrm{IC}_{50}$ 60-166 $\mu \mathrm{M})$ and its dimer 3 is much more cytotoxic $\left(\mathrm{IC}_{50} 8-44 \mu \mathrm{M}\right)$. In contrast, 2,3-dehydrosilybin 6, with an $\mathrm{IC}_{50}$ of $12-59 \mu \mathrm{M}$, is significantly more cytotoxic than the mixed 2,3-dehydrosilybin dimer (7), $\mathrm{IC}_{50} 99-173 \mu \mathrm{M}$, Table 2. These results follow a similar trend as the effect of the dimers on DPPH scavenging and microsomal lipoperoxidation. No data about the cytotoxicity of flavonolignan dimers are available in the literature. Nevertheless, a spontaneously formed heterodimer of the flavonol quercetin with quite a rigid structure was recently found to be responsible for its cytotoxicity towards MDA-MB-231 cells [38]. Biological activity towards P-glycoprotein-based multidrug resistance was evaluated for various synthetic luteolin dimers in multidrug resistant MDA435/LCC6 breast cancer 
cells and was found to be strongly influenced by the length of the linker used. Dimers with spacers between two and four ethylene glycols were effective at reversing multidrug resistance, while dimers with shorter or longer spacers exhibited little or no effect [21].

Table 2. Effect of selected compounds on viability of endothelial cells (HUVEC), keratinocytes (NAK), fibroblasts (BALB/c 3T3) and hepatoma epithelial cells (HepG2) a .

\begin{tabular}{ccccc}
\hline & HUVEC & NAK & BALB/c 3T3 & HepG2 \\
\hline $\mathbf{1 a}$ & $57.8 \pm 3.6^{\mathrm{b}}$ & $>200$ & $130.7 \pm 8.0$ & $165.4 \pm 8.1$ \\
$\mathbf{3}$ & $7.6 \pm 1.9^{\mathrm{b}}$ & $>200$ & $23.5 \pm 5.6^{\mathrm{b}}$ & $51.8 \pm 5.9^{\mathrm{b}}$ \\
$\mathbf{6}$ & $20.9 \pm 4.6^{\mathrm{c}}$ & $>200$ & $11.9 \pm 3.0$ & $58.4 \pm 9.0$ \\
$\mathbf{7}$ & $98.4 \pm 10.6^{\mathrm{c}}$ & $>200$ & $161.4 \pm 9.0^{\mathrm{c}}$ & $172.5 \pm 11.6^{\mathrm{c}}$ \\
\hline
\end{tabular}

a The cells were grown in 96-well plates to near confluence, then incubated with the tested compounds for $24 \mathrm{~h}$ and MTT-reducing ability was expressed as $\mathrm{IC}_{50}[\mu \mathrm{M}]($ mean $\pm \mathrm{SD}$ from three independent experiments performed in triplicates); ${ }^{\mathrm{b}} p<0.05$ compared with $\mathbf{1 a} ;{ }^{\mathrm{c}} p<0.05$ compared with $\mathbf{6}$.

Taken together, these results led us to the hypothesis that in 2,3-dehydrosilybin 6, dimerization using a flexible aliphatic ester linker probably resulted in the $\pi$-stacking of the two 2,3-dehydrosilybin units together and the blocking of some active groups. Similar inter and intra-molecular $\pi$-stacking was described, confirmed experimentally [39] and by means of molecular modelling [40,41] to be involved e.g., in copigmentation of anthocyanins and synthesis of oligostilbenoids [42]. Comparison of the hydration constants of various delphidin-based pigments revealed clearly that this type of interaction will be stronger for molecules with longer and more linear chains with greater flexibility. Moreover, a flat aromatic structure is required for $\pi$-stacking to occur [39]. Indeed, while the flavonoid part of 2,3-dehydrosilybin $\mathbf{6}$ was found to be planar, allowing $\pi$-electron delocalization, in silybin $\mathbf{1}$, the planarity is lost with a strong distortion $\left(\Phi\right.$ ca $\left.74^{\circ}\right)$ due to the loss of the 2,3-double bond and subsequently the loss of $\pi$-electron delocalization [16]. П-stacking is, therefore, much more probable to occur in the dimer 7 compared to the compound 3. In both tests, the DPPH and lipoperoxidation assays, the double bond between C-2 and C-3 and also unoccupied hydroxyl groups in positions C-3, C-5 and C-7 are essential for its high antioxidant properties. They play an important role in the mechanism of resonance stabilization which leads to a stable resonance structure $[8,16]$. The stacking of two units of 2,3-dehydrosilybin in the dimer molecule can block one or more hydroxyl groups and make resonance stabilization impossible, which probably decreases the reactivity and antioxidant activity of the 2,3-dehydrosilybin dimer.

\section{Experimental}

\subsection{Chemicals and Reagents}

Optically pure silybin A and B were prepared from commercial silymarin according to the published procedure [43]. $p$-Xylylene dibromide was obtained from ABCR (Karlsruhe, Germany). Other chemicals were obtained from Sigma-Aldrich (Prague, Czech Republic). Reactions were monitored by TLC (silica gel/TLC sheets $60 \mathrm{~F}_{254}$ Merck, Darmstadt, Germany). The lipase B from Candida antarctica immobilized on acrylic resin (Novozym 435) was purchased from Novo-Nordisk (Bagsvaerd, Denmark). 
Dimethyl sulfoxide (DMSO) for cell cultures, 1,1-diphenyl-2-picrylhydrazyl (DPPH), Dulbecco's modified Eagle's medium (DMEM), MTT (3-(4,5-dimethyl-2-thiazolyl)-2,5-diphenyl-2H-tetrazolium bromide), streptomycin, penicillin, glutamine, trypsin-EDTA $(0.25 \%)$, tert-butylhydroperoxide $(t$-BH, $70 \%$ ), foetal calf serum (FCS) and newborn FCS were purchased from Sigma-Aldrich. Collagenase was from Serva (Heidelberg, Germany). Endothelial Cell Basal Medium with growth factors (Endothelial Growth Medium, EGM) was from Promocell (Heidelberg, Germany), EpiLife medium (M-EPI-500-CA) and Human Keratinocyte Growth Supplement (HKGS) from Life Technologies (Prague, Czech Republic). Other chemicals and solvents were of analytical grade from Pliva-Lachema (Brno, Czech Republic). For lipid peroxidation and cytotoxicity measurement, the tested compounds were dissolved in $10 \mathrm{mM}$ of DMSO and these stock solutions were kept at $-20{ }^{\circ} \mathrm{C}$.

\subsection{General Methods}

NMR spectra were measured with a Bruker AVANCE III $600 \mathrm{MHz}$ spectrometer $(600.23 \mathrm{MHz}$ for ${ }^{1} \mathrm{H}$, and $150.93 \mathrm{MHz}$ for ${ }^{13} \mathrm{C}$ ) in DMSO- $d_{6}, 30{ }^{\circ} \mathrm{C}$. The residual signal of the solvent was used as an internal standard $\left(\delta_{\mathrm{H}} 3.330, \delta_{\mathrm{C}} 49.30\right) .{ }^{1} \mathrm{H}-\mathrm{NMR},{ }^{13} \mathrm{C}-\mathrm{NMR}$, COSY, HSQC, and HMBC spectra were measured using the standard manufacturer's software. Chemical shifts are given in $\delta$-scale [ppm], and coupling constants in Hz. The digital resolution enabled us to report chemical shifts of protons to three and carbon chemical shifts to two decimal places. Some hydrogen chemical shifts were read out from the HSQC and are reported to two decimal places. Mass spectra were measured with a Micromass Platform LC system in methanol with the addition of formic acid. Reaction mixtures were incubated in a Thermomixer (Eppendorf, Hamburg, Germany).

\subsection{Chemistry}

\subsubsection{Synthesis of 12-Vinyl Dodecanedioate-23-O-Silybin B (2b)}

Silybin B (1b, 1 mmol, 1 eq.) and divinylester of dodecanedioic acid [24] (2.624 mmol, 2.6 eq.) were dissolved in anhydrous acetonitrile $(15 \mathrm{~mL})$. Novozym $435(200 \mathrm{mg})$ and $4 \AA$ molecular sieves (200 mg) were added to the solution. The reaction mixture was incubated at $45{ }^{\circ} \mathrm{C}, 500 \mathrm{rpm}$. After $24 \mathrm{~h}$, the reaction was terminated by filtering off the enzyme and the solvent was evaporated under reduced pressure. The crude product $\mathbf{2 b}$ was purified by silica gel flash chromatography (chloroform/acetone 85:15).

1-((3-(4-Hydroxy-3-methoxyphenyl)-6-(3,5,7-trihydroxy-4-oxochroman-2-yl)-2,3-dihydrobenzo[b][1,4]dioxin-2-yl)methyl) 12-vinyl dodecanedioate (12-vinyl dodecanedioate-23-O-silybin B) (2b). White solid (yield 38\%, $235 \mathrm{mg}, 0.326 \mathrm{mmol}$ ). For ${ }^{1} \mathrm{H}$ and ${ }^{13} \mathrm{C}-\mathrm{NMR}$ data, see Tables $\mathrm{S} 1$ and $\mathrm{S} 2$ in the Supporting Information. MS-ESI $m / z$ : $[\mathrm{M}+\mathrm{H}]^{+}$Calcd. for $\mathrm{C}_{39} \mathrm{H}_{45} \mathrm{O}_{13}$ 721.5; Found: 721.3.

\subsubsection{General Procedure-Preparation of Diesters 3 and 4}

Silybin (1a or 1b, $0.621 \mathrm{mmol}, 2.7$ eq.) and divinyldodecanedioate (0.230 mmol, 1 eq.) were dissolved in anhydrous acetonitrile $(9 \mathrm{~mL})$. Novozym $435(150 \mathrm{mg})$ and $4 \AA$ molecular sieves $(50 \mathrm{mg})$ were added to the solution. The reaction mixture was incubated at $45{ }^{\circ} \mathrm{C}, 500 \mathrm{rpm}$. After $72 \mathrm{~h}$, the 
reaction was stopped by filtering off the enzyme and the solvent was evaporated under reduced pressure. The crude product was purified by gel filtration using Sephadex LH 20 column, $140 \times 1.8 \mathrm{~cm}\left(\right.$ eluent $\left.\mathrm{MeOH} / \mathrm{H}_{2} \mathrm{O} 4: 1\right)$.

bis(((2R,3R)-3-(4-Hydroxy-3-methoxyphenyl)-6-((2R,3R)-3,5,7-trihydroxy-4-oxochroman-2-yl)-2,3dihydrobenzo[b] [1,4]dioxin-2-yl)methyl) dodecanedioate (3). White solid (yield 24\%, $86 \mathrm{mg}$ ). For ${ }^{1} \mathrm{H}$ and ${ }^{13} \mathrm{C}-\mathrm{NMR}$ data, see Tables $\mathrm{S} 1$ and $\mathrm{S} 2$ in the Supporting Information. MS-ESI $m / z:[\mathrm{M}+\mathrm{H}]^{+} \mathrm{Calcd}$. for $\mathrm{C}_{62} \mathrm{H}_{63} \mathrm{O}_{22}$ 1158.4; Found 1158.3.

bis(((2S,3S)-3-(4-Hydroxy-3-methoxyphenyl)-6-((2R,3R)-3,5,7-trihydroxy-4-oxochroman-2-yl)-2,3dihydrobenzo[b] [1,4]dioxin-2-yl)methyl) dodecanedioate (4). White solid (yield 44\%, $118 \mathrm{mg}$ ). For ${ }^{1} \mathrm{H}$ and ${ }^{13} \mathrm{C}-\mathrm{NMR}$ data, see Tables $\mathrm{S} 1$ and $\mathrm{S} 2$ in the Supporting Information. MS-ESI $m / z:[\mathrm{M}+\mathrm{H}]^{+} \mathrm{Calcd}$. for $\mathrm{C}_{62} \mathrm{H}_{63} \mathrm{O}_{22}$ 1158.4; Found 1158.4.

\subsubsection{Preparation of Mixed Dimer 5}

12-Vinyl dodecanedioate-23- $O$-silybin B (2b, 0.278 mmol, 1 eq.) and silybin A (1a, 0.556 mmol, 2 eq.) were dissolved in anhydrous acetonitrile $(9 \mathrm{~mL})$. Novozym $435(100 \mathrm{mg})$ and $4 \AA$ molecular sieves $(100 \mathrm{mg})$ were added to the solution. The reaction mixture was incubated at $45{ }^{\circ} \mathrm{C}, 500 \mathrm{rpm}$. After $72 \mathrm{~h}$, the reaction was stopped by filtering off the enzyme and the solvent was evaporated under reduced pressure. The crude product was purified by gel filtration using Sephadex LH 20 column $140 \times 1.8 \mathrm{~cm}$ (eluent $\left.\mathrm{MeOH} / \mathrm{H}_{2} \mathrm{O} 4: 1\right)$.

1-(((2R,3R)-3-(4-Hydroxy-3-methoxyphenyl)-6-((2R,3R)-3,5,7-trihydroxy-4-oxochroman-2-yl)-2,3-

dihydrobenzo[b][1,4]dioxin-2-yl)methyl) 12-(((2S,3S)-3-(4-hydroxy-3-methoxyphenyl)-6-((2R,3R)3,5,7-trihydroxy-4-oxochroman-2-yl)-2,3-dihydrobenzo[b][1,4]dioxin-2-yl)methyl) dodecanedioate (5). White solid (yield 26\%, $85 \mathrm{mg}$ ). For ${ }^{1} \mathrm{H}$ and ${ }^{13} \mathrm{C}-\mathrm{NMR}$ data, see Tables $\mathrm{S} 1$ and $\mathrm{S} 2$ in the Supporting Information. MS-ESI m/z: [M+H] $]^{+}$Calcd. for $\mathrm{C}_{62} \mathrm{H}_{63} \mathrm{O}_{22}$ 1158.1; Found 1158.1 .

\subsubsection{Preparation 2,3-Dehydrosilybin Dimer 7}

2,3-Dehydrosilybin (6, $0.416 \mathrm{mmol}, 4$ eq.) and the divinylester of dodecanedioic acid (0.104 mmol, 1 eq.) were dissolved in anhydrous acetone $(20 \mathrm{~mL})$. Novozym $435(200 \mathrm{mg})$ and $4 \AA$ molecular sieves $\left(50 \mathrm{mg}\right.$ ) were added to the solution. The reaction mixture was incubated at $45^{\circ} \mathrm{C}, 500$. After $16 \mathrm{~h}$, the reaction was stopped by filtering off the enzyme and the solvent was evaporated under reduced pressure. The crude product was purified by flash chromatography $\left(\mathrm{CHCl}_{3} /\right.$ acetone $\left.4: 1\right)$.

bis((3-(4-Hydroxy-3-methoxyphenyl)-6-(3,5,7-trihydroxy-4-oxo-4H-chromen-2-yl)-2,3-dihydrobenzo[b][1,4]dioxin-2-yl)methyl) dodecanedioate (7). Yellow solid (yield 19\%, $90 \mathrm{mg}$ ). For ${ }^{1} \mathrm{H}$ and ${ }^{13} \mathrm{C}$-NMR data, see the Supporting Information. MS-ESI $\mathrm{m} / \mathrm{z}$ : $[\mathrm{M}+\mathrm{H}]^{+}$Calcd. for $\mathrm{C}_{62} \mathrm{H}_{58} \mathrm{O}_{22} 1153.8$; Found 1153.8. HRMS [M+Na] ${ }^{+}$Calcd. 1177.3317; Found 1177.3328. 


\subsubsection{General Procedure: Preparation of Silybin Diethers 8, 9, 10 and 11}

$\mathrm{K}_{2} \mathrm{CO}_{3}$ (5.8 mmol, 7 eq.) and $p$-xylylene dibromide ( $0.42 \mathrm{mmol}, 0.5$ eq.) or $m$-xylylene dibromide ( $0.42 \mathrm{mmol}, 0.5$ eq.) were added to the solution of silybin ( 1 or $\mathbf{1 a}$ or $\mathbf{1 b}, 400 \mathrm{mg}, 0.83 \mathrm{mmol}, 1$ eq.) in dry acetone $(20 \mathrm{~mL})$. The mixture was stirred and refluxed for $4 \mathrm{~h}$ under nitrogen. The reaction was quenched by the addition of conc. $\mathrm{HCl}(1 \mathrm{~mL})$, diluted with water $(50 \mathrm{~mL})$ and extracted with ethyl acetate $(2 \times 30 \mathrm{~mL})$. The organic layer was dried over $\mathrm{Na}_{2} \mathrm{SO}_{4}$ and evaporated. The residue was purified by flash chromatography (linear gradient from chloroform/acetone 85:15 to acetone 100\%) and the title compound was isolated as a white amorphous solid.

$\left(2 R, 2^{\prime} R, 3 R, 3^{\prime} R\right)-7,7^{\prime}-((1,4-P h e n y l e n e b i s(m e t h y l e n e))$ bis (oxy)) bis(3,5-dihydroxy-2-((2R,3R)-3-(4hydroxy-3-methoxyphenyl)-2-(hydroxymethyl)-2,3-dihydrobenzo[b][1,4]dioxin-6-yl)chroman-4-one) (8). This compound was prepared according to the general procedure from 1a and $p$-xylylene dibromide. Product was isolated as a white solid (yield 7\%, $30 \mathrm{mg}$ ). For ${ }^{1} \mathrm{H}$ and ${ }^{13} \mathrm{C}-\mathrm{NMR}$ data, see Tables $\mathrm{S} 1$ and $\mathrm{S} 3$ in the Supporting Information. MS-ESI $m / z$ : $[\mathrm{M}-\mathrm{H}]^{+}$Calcd. for $\mathrm{C}_{58} \mathrm{H}_{50} \mathrm{O}_{20} 1065.5$; Found 1065.5.

$\left(2 R, 2^{\prime} R, 3 R, 3^{\prime} R\right)-7,7^{\prime}-((1,4-P h e n y l e n e b i s(m e t h y l e n e))$ bis(oxy)) bis(3,5-dihydroxy-2-((2S,3S)-3-(4hydroxy-3-methoxyphenyl)-2-(hydroxymethyl)-2,3-dihydrobenzo[b][1,4]dioxin-6-yl)chroman-4-one) (9). This compound was prepared according to the general procedure from $\mathbf{1 b}$ and $p$-xylylene dibromide. Product was isolated as a white solid (yield 9\%, $35 \mathrm{mg}$ ). For ${ }^{1} \mathrm{H}$ and ${ }^{13} \mathrm{C}-\mathrm{NMR}$ data, see Tables $\mathrm{S} 1$ and $\mathrm{S} 3$ in the Supporting Information. MS-ESI $m / z$ : $[\mathrm{M}-\mathrm{H}]^{+}$Calcd. for $\mathrm{C}_{58} \mathrm{H}_{50} \mathrm{O}_{20}$ 1065.4; Found 1065.4.

$\left(2 R, 2^{\prime} R, 3 R, 3^{\prime} R\right)-7,7^{\prime}-((1,4-P h e n y l e n e b i s(m e t h y l e n e))$ bis(oxy)) bis(3,5-dihydroxy-2-(3-(4-hydroxy-3methoxyphenyl)-2-(hydroxymethyl)-2,3-dihydrobenzo[b][1,4]dioxin-6-yl)chroman-4-one) (10). This compound was prepared according to the general procedure from $\mathbf{1}$ and $p$-xylylene dibromide. Product was isolated as a white solid (yield 15\%, $40 \mathrm{mg}$ ). For ${ }^{1} \mathrm{H}$ and ${ }^{13} \mathrm{C}-\mathrm{NMR}$ data, see Tables $\mathrm{S} 1$ and S3 in the Supporting Information. MS-ESI $m / z$ : $[\mathrm{M}-\mathrm{H}]^{+}$Calcd. for $\mathrm{C}_{58} \mathrm{H}_{50} \mathrm{O}_{20}$ 1065.5; Found 1065.3.

$\left(2 R, 2^{\prime} R, 3 R, 3^{\prime} R\right)-7,7^{\prime}-((1,3-P h e n y l e n e b i s(m e t h y l e n e))$ bis(oxy)) bis(3,5-dihydroxy-2-(3-(4-hydroxy-3methoxyphenyl)-2-(hydroxymethyl)-2,3-dihydrobenzo[b][1,4]dioxin-6-yl)chroman-4-one) (11). This compound was prepared according to the general procedure from 1 and $m$-xylylene dibromide. Product was isolated as a white solid (yield 14\%, $30 \mathrm{mg}$ ). For ${ }^{1} \mathrm{H}$ and ${ }^{13} \mathrm{C}-\mathrm{NMR}$ data, see Tables S1 and S3 in the Supporting Information. MS-ESI $m / z$ : $[\mathrm{M}-\mathrm{H}]^{+}$Calcd. for $\mathrm{C}_{58} \mathrm{H}_{50} \mathrm{O}_{20}$ 1065.5; Found 1065.5.

\subsection{Stability of Dimers-HPLC Analysis}

The stability of the dimers in PBS buffer and phosphate buffer (0.2 M, pH 7.4) was monitored using an HPLC method. $40 \mathrm{mM}$ solutions of compounds $\mathbf{4}$ and $\mathbf{1 0}$ in DMSO were diluted with $2 \mathrm{~mL}$ of each buffers and incubated for $24 \mathrm{~h}$ at room temperature. The chromatography was carried out in a Shimadzu Prominence UFLC system (Kyoto, Japan) consisting of a DGU-20A mobile phase degasser, two LC-20AD solvent delivery units, SIL-20ACHT cooling autosampler, CTO-10AS column oven and SPD-M20A (PDA, photodiode array detector). A Chromolith Performance RP-18e monolithic column $(100 \times 3 \mathrm{~mm}$ i.d. $)$ and guard column $(5 \times 4.6 \mathrm{~mm}$ i.d., both Merck $)$ were used. The PDA data were acquired in the $200-450 \mathrm{~nm}$ range and the 285 signal was extracted. Gradient elution: mobile 
phase A: $0.1 \%$ formic acid, $10 \%$ methanol in water $(\mathrm{v} / \mathrm{v} / \mathrm{v})$; mobile phase $\mathrm{B}: 0.1 \%$ formic acid in methanol $(v / v)$; gradient, $0-1 \mathrm{~min}, 20 \% \mathrm{~B}$; 1-8 min, 20\%-90\% B; 8-9 min, 90\% B, 9-10 min, $90 \%-20 \%$ B. The flow rate was $1.2 \mathrm{~mL} / \mathrm{min}$ at $25^{\circ} \mathrm{C}$.

\subsection{Electrochemical Measurement}

The monomeric flavonolignans and their dimers were analyzed using in situ voltammetry with the working electrode (PGE: pyrolytic graphite electrode) dipped in the supporting electrolyte containing the analytes and/or ex situ voltammetric analysis (adsorptive transfer, AdT technique). For this purpose, the PGE was first dipped into a $5 \mu \mathrm{L}$ aliquot of the studied sample. After an accumulation period (30 s), the electrode was washed with deionized water and placed in an electrochemical cell containing pure supporting electrolyte. Square-wave voltammetry (SWV) and cyclic voltammetry (CV) were performed at room temperature with a $\mu$ Autolab III analyzer (EcoChemie, Utrecht, The Netherlands) in a three-electrode setup $(\mathrm{Ag} / \mathrm{AgCl} 3 \mathrm{M} \mathrm{KCl}$ electrode as a reference and a platinum wire as the auxiliary electrode). SWV parameters: frequency: $200 \mathrm{~Hz}$, from $0 \mathrm{~V}$ to $+1.5 \mathrm{~V}$, concentration of tested compounds $(50 \mu \mathrm{M})$, supporting electrolyte: Britton-Robinson buffer, $\mathrm{pH}$ 7.4. The

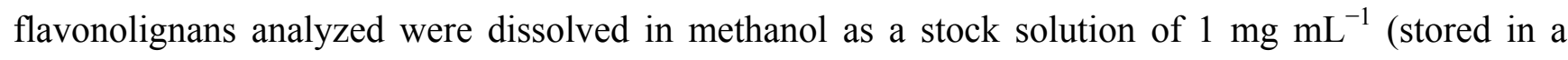
fridge in the dark), and diluted with the supporting electrolyte and/or $0.2 \mathrm{M}$ acetate buffer (pH 5) for in situ and/or ex situ voltammetry. Ex situ a.c. voltammetry (out-of-phase) was carried out with a hanging mercury drop electrode (HMDE) according to the previously published paper [44]. In this case, the flavonolignans $(50 \mu \mathrm{M})$ were adsorbed from $0.2 \mathrm{M}$ acetate buffer $(\mathrm{pH}$ 5) for $30 \mathrm{~s}$. For current responses and potentials $\left(E_{\mathrm{p}}\right)$, the standard deviations (S.D.) were less than $\pm 3.55 \%$ and $\pm 3 \mathrm{mV}$ for all experiments, respectively.

\subsection{DPPH Assay}

Antiradical activity was evaluated spectrophotometrically as the ability of the tested substances to reduce the 1,1-diphenyl-2-picrylhydrazyl (DPPH) radical as described previously [45] with minor modifications. Briefly, a solution of the tested substance $(10 \mu \mathrm{L}$, final concentration $0-540 \mu \mathrm{M})$ were mixed with a freshly prepared methanolic DPPH solution $(290 \mu \mathrm{L}$, final concentration $20 \mu \mathrm{M})$ in a microtiter plate well. After $30 \mathrm{~min}$, absorbance at $517 \mathrm{~nm}$ was measured, percentages of inhibition were calculated using the negative control and for selected compounds the $\mathrm{IC}_{50}$ values were obtained from the inhibition curves.

\subsection{Inhibition of Microsomal Lipid Peroxidation}

Microsomes were prepared from rat liver homogenate as described previously [46] and resuspended in $50 \mathrm{mM}$ Tris- $\mathrm{HCl}$ buffer with $100 \mathrm{mM} \mathrm{KCl}$ and $0.1 \mathrm{mM}$ EDTA (pH 7.4). The protein concentration in the stock microsomal suspension was determined using the Bradford method [47] to be typically ca $30 \mathrm{mg}$ protein $/ \mathrm{mL}$. This stock suspension was stored at $-80{ }^{\circ} \mathrm{C}$ and diluted to $0.625 \mathrm{mg}$ protein $/ \mathrm{mL}$ using PBS before use. $0.4 \mathrm{~mL}$ of the diluted microsomal suspension was then mixed with the compounds tested (final concentration 10-200 $\mu \mathrm{M}$ in $0.01 \mathrm{~mL}$ DMSO) and incubated for 10 min at $37{ }^{\circ} \mathrm{C}$. tert-Butyl hydroperoxide $(0.09 \mathrm{~mL}$ in PBS; final concentration $1 \mathrm{mM})$ was then added and 
the mixture was incubated at $37^{\circ} \mathrm{C}$ for $30 \mathrm{~min}$. The products of lipid peroxidation were determined as thiobarbituric acid reactive substances (TBARS): $0.7 \mathrm{~mL}$ of trichloroacetic acid $(26 \mathrm{mM})$ with thiobarbituric acid $(918 \mathrm{mM})$ were added, the mixture was heated $\left(90^{\circ} \mathrm{C} ; 30 \mathrm{~min}\right)$, cooled, centrifuged (10 min; $10,000 \mathrm{rpm} ; 4{ }^{\circ} \mathrm{C}$ ) and the absorbance of the supernatant at $535 \mathrm{~nm}$ measured. The activity was calculated as the concentration of the tested compound that inhibited the color reaction with thiobarbiturate (without the tested compound) by $50 \%$ ( $\left.\mathrm{IC}_{50}\right)$.

\subsection{Source of Human Tissues}

Human umbilical cords and skin samples were obtained from healthy volunteers, who had to fulfill the requirements for submission to the study and sign a personal awareness declaration. The choice of volunteers was in accordance with the principles of the International Ethics Committee for Biomedical Research [48] and the study was approved by the Ethics Commission of Palacký University and University Hospital in Olomouc.

\subsection{Cell Cultures}

All the cells were cultured in a humidified atmosphere with $5 \%(v / v) \mathrm{CO}_{2}$ at $37{ }^{\circ} \mathrm{C}$ and subcultured before confluence. Human Umbilical Vein Endothelial Cells (HUVEC) were isolated from umbilical cords of healthy non-smoker women (18-35 years) as described previously [49], cultivated in gelatin-coated flasks in EGM and used in passages 2-6. Primary Normal human Adult epidermal Keratinocytes (NAK) were isolated from normal skin obtained from excessive tissue removed during abdominoplasty or mammoplasty of healthy adult patients as described in [36,50], cultivated in EpiLife medium with the addition of HKGS. Mouse fibroblasts (BALB/c 3T3 cells) were purchased from the European Collection of Cell Cultures (ECACC, Salisbury, UK) and were grown in DMEM supplemented with heat-inactivated FCS $(5 \%, v / v)$ and newborn FCS, streptomycin $(100 \mathrm{U} / \mathrm{mL})$, penicillin $(0.1 \mathrm{mg} / \mathrm{mL})$ and glutamine $(4 \mathrm{mM})$. Hepatocyte carcinoma HepG2 cells (No. 85011430, ECACC) were cultured at $37{ }^{\circ} \mathrm{C}$ in DMEM supplemented with $2 \mathrm{mM}$ L-glutamine, $1 \%$ non-essential amino acids, $100 \mathrm{U} / \mathrm{mL}$ penicillin, $100 \mathrm{mg} / \mathrm{mL}$ streptomycin and $10 \%$ fetal bovine serum (Invitrogen, Carlsbad, CA, USA).

\subsection{Cytotoxicity Testing}

The cells were plated into 96-well cell culture plates and grown to near confluence. The tested compounds were placed in the respective fresh medium in serial dilutions (100 $\mu \mathrm{L} /$ well) and incubated with the cells for $24 \mathrm{~h}$. After incubation, the medium was removed, the cells were washed with PBS, fresh medium containing $1 \mathrm{mg} / \mathrm{mL}$ of MTT was added and the plates were incubated for a further $3 \mathrm{~h}$ $\left(37^{\circ} \mathrm{C}\right)$. The resulting formazan was dissolved in $50 \mu \mathrm{L}$ of $1 \% \mathrm{NH}_{3}$ in $\mathrm{DMSO}$, absorbance was read at $540 \mathrm{~nm}$ and $\mathrm{IC}_{50}$ values were obtained graphically from the dependence of cell viability on the concentration of the tested compound. 


\subsection{Statistical Analysis}

Data were analyzed with one-way ANOVA using the statistical package statext ver. 2.1. Differences were considered statistically significant when $p<0.05$.

\section{Conclusions}

Divalent or multivalent molecules can modulate and promote biological activity compared to their monomers. Two different types of silybin or 2,3-dehydrosilybin dimers, differing in the connection of their monomeric units, were prepared and characterized. Electrochemical measurements show that mechanism of oxidation of all dimeric compounds ( $v s$. parent molecules) is probably the same. The specific adsorption behavior onto the electrode surface indicates that the dimers could probably specifically interact with biomacromolecules and membranes and that this would influence their reactivity and uptake into cells, which was confirmed by various biological in vitro tests. The DPPH-scavenging and inhibition of microsomal lipid peroxidation was slightly improved by dimerization with silybin; but the dimer exhibited a higher cytotoxicity (HUVEC, BALB/c 3T3, HepG2) than the parent compound. In contrast to this, the dimer of 2,3-dehydrosilybin exhibited a significant lowering of both DPPH-scavenging and antilipoperoxidant activity, and a lower cytotoxicity compared to 2,3-dehydrosilybin. This behavior might be caused by the stacking of the aromatic 2,3-dehydrosilybin moieties in the dimer. We assume that knowledge on the basic redox, antioxidant and toxicological properties of the novel flavonolignan dimers presented here can be applied in subsequent more complex biological studies.

\section{Supplementary Materials}

Supplementary data containing ${ }^{1} \mathrm{H}$ and ${ }^{13} \mathrm{C}-\mathrm{NMR}$ and MS data associated with this article can be found, in the online version, at: http://www.mdpi.com/1420-3049/19/4/4115/s1.

\section{Acknowledgments}

Financial support from the Czech Science Foundation, project P303/12/G163, Ministry of Education of the Czech Republic project LD13041, and a COST chemistry action CM1001 is gratefully acknowledged. A. Balharová, E. Lepařová, S. Snášelová and V. Pivodová (Palacky University, Olomouc) are thanked for their excellent technical assistance. The authors are indebted to I. Oborná and B. Zálešák (Department of Obstetrics and Gynecology and Department of Plastic and Aesthetic Surgery, University Hospital in Olomouc) for their kind donation of human umbilical cords and skin samples.

\section{Author Contributions}

E.V. synthetized all the new compounds, J.V. performed the voltammetric measurement and DPPH scavenging screening, K.V. was responsible for the determination of $\mathrm{IC}_{50}$ values for $\mathrm{DPPH}$ scavenging, inhibition of lipid peroxidation and cytotoxicity evaluation. P.M. did the stability studies including 
HPLC, M.K. measured the NMRs. J.U. and V.K. designed the experiments. All the authors contributed to the manuscript writing.

\section{Conflicts of Interest}

The authors declare no conflict of interest.

\section{References}

1. Gazak, R.; Walterova, D.; Kren, V. Silybin and silymarin-New and emerging applications in medicine. Curr. Med. Chem. 2007, 14, 315-338.

2. Kren, V.; Gazak, R.; Purchartova, K.; Marhol, P.; Biedermann, D.; Sedmera, P. Chemoenzymatic preparative separation of silybins A and B. J. Mol. Catal. B: Enzymat. 2009, 61, 247-251.

3. Gazak, R.; Trouillas, P.; Biedermann, D.; Fuksova, K.; Marhol, P.; Kuzma, M.; Kren, V. Base-catalyzed oxidation of silybin and isosilybin into 2,3-dehydro derivatives. Tetrahedron Lett. 2013, 54, 315-317.

4. Huber, A.; Thongphasuk, P.; Erben, G.; Lehmann, W.D.; Tuma, S.; Stremmel, W.; Chamulitrat, W. Significantly greater antioxidant anticancer activities of 2,3-dehydrosilybin than silybin. Biochim. Biophys. Acta 2008, 1780, 837-847.

5. Thongphasuk, P.; Stremmel, W.; Chamulitrat, W. 2,3-dehydrosilybin is a better DNA topoisomerase I inhibitor than its parental silybin. Chemotherapy 2009, 55, 42-48.

6. Gazak, R.; Svobodova, A.; Psotova, J.; Sedmera, P.; Prikrylova, V.; Walterova, D.; Kren, V. Oxidised derivatives of silybin and their antiradical and antioxidant activity. Bioorg. Med. Chem. 2004, 12, 5677-5687.

7. Zatloukalova, M.; Kren, V.; Gazak, R.; Kubala, M.; Trouillas, P.; Ulrichova, J.; Vacek, J. Electrochemical investigation of flavonolignans and study of their interactions with DNA in the presence of $\mathrm{Cu}(\mathrm{II})$. Bioelectrochemistry 2011, 82, 117-124.

8. Gazak, R.; Sedmera, P.; Vrbacky, M.; Vostalova, J.; Drahota, Z.; Marhol, P.; Walterova, D.; Kren, V. Molecular mechanisms of silybin and 2,3-dehydrosilybin antiradical activity-Role of individual hydroxyl groups. Free Radic. Biol. Med. 2009, 46, 745-758.

9. Gazak, R.; Purchartova, K.; Marhol, P.; Zivna, L.; Sedmera, P.; Valentova, K.; Kato, N.; Matsumura, H.; Kaihatsu, K.; Kren, V. Antioxidant and antiviral activities of silybin fatty acid conjugates. Eur. J. Med. Chem. 2010, 45, 1059-1067.

10. Theodosiou, E.; Katsoura, M.H.; Loutrari, H.; Purchartova, K.; Kren, V.; Kolisis, F.N.; Stamatis, H. Enzymatic preparation of acylated derivatives of silybin in organic and ionic liquid media and evaluation of their antitumor proliferative activity. Biocatal. Biotrans. 2009, 27, 161-169.

11. Theodosiou, E.; Loutrari, H.; Stamatis, H.; Roussos, C.; Kolisis, F.N. Biocatalytic synthesis and antitumor activities of novel silybin acylated derivatives with dicarboxylic acids. New Biotechnol. 2011, 28, 342-348.

12. Monti, D.; Gazak, R.; Marhol, P.; Biedermann, D.; Purchartova, K.; Fedrigo, M.; Riva, S.; Kren, V. Enzymatic kinetic resolution of silybin diastereoisomers. J. Nat. Prod. 2010, 73, 613-629. 
13. Chen, X.Y.; Zenger, K.; Lupp, A.; Kling, B.; Heilmann, J.; Fleck, C.; Kraus, B.; Decker, M. Tacrine-silibinin codrug shows neuro- and hepato protective effects in vitro and pro-cognitive and hepatoprotective effects in vivo. J. Med. Chem. 2012, 55, 5231-5242.

14. Zarrelli, A.; Romanucci, V.; Greca, M.D.; de Napoli, L.; Previtera, L.; di Fabio, G. New silybin scaffold for chemical diversification: Synthesis of novel 23-phosphodiester silybin conjugates. Synlett 2013, 24, 45-48.

15. Gazak, R.; Sedmera, P.; Marzorati, M.; Riva, S.; Kren, V. Laccase-mediated dimerization of the flavonolignan silybin. J. Mol. Catal. B 2008, 50, 87-92.

16. Trouillas, P.; Marsal, P.; Svobodova, A.; Vostalova, J.; Gazak, R.; Hrbac, J.; Sedmera, P.; Kren, V.; Lazzaroni, R.; Duroux, J.L.; et al. Mechanism of the antioxidant action of silybin and 2,3-dehydrosilybin flavonolignans: A joint experimental and theoretical study. J. Phys. Chem. A 2008, 112, 1054-1063.

17. Pliskova, M.; Vondracek, J.; Kren, V.; Gazak, R.; Sedmera, P.; Walterova, D.; Psotova, J.; Simanek, V.; Machala, M. Effects of silymarin flavonolignans and synthetic silybin derivatives on estrogen and aryl hydrocarbon receptor activation. Toxicology 2005, 215, 80-89.

18. Berube, G. Natural and synthetic biologically active dimeric molecules: Anticancer agents, anti-hiv agents, steroid derivatives and opioid antagonists. Curr. Med. Chem. 2006, 13, 131-154.

19. Mott, B.T.; Tripathi, A.; Siegler, M.A.; Moore, C.D.; Sullivan, D.J.; Posner, G.H. Synthesis and antimalarial efficacy of two-carbon-linked, artemisinin-derived trioxane dimers in combination with known antimalarial drugs. J. Med. Chem. 2013, 56, 2630-2641.

20. Jenett-Siems, K.; Kohler, I.; Kraft, C.; Pertz, H.H.; Kren, V.; Fiserova, A.; Kuzma, M.; Ulrichova, J.; Bienzle, U.; Eich, E. In vitro antiplasmodial activities of semisynthetic N,N'-spacer-linked oligomeric ergolines. Bioorg. Med. Chem. 2004, 12, 817-824.

21. Chan, K.F.; Zhao, Y.Z.; Burkett, B.A.; Wong, I.L.K.; Chow, L.M.C.; Chan, T.H. Flavonoid dimers as bivalent modulators for P-glycoprotein-based multidrug resistance: Synthetic apigenin homodimers linked with defined-length poly(ethylene glycol) spacers increase drug retention and enhance chemosensitivity in resistant cancer cells. J. Med. Chem. 2006, 49, 6742-6759.

22. Dolle, C.; Magrone, P.; Riva, S.; Ambrosi, M.; Fratini, E.; Peruzzi, N.; Lo Nostro, P. Symmetric and asymmetric bolaamphiphiles from ascorbic acid. J. Phys. Chem. B 2011, 115, 11638-11649.

23. Chebil, L.; Humeau, C.; Falcimaigne, A.; Engasser, J.M.; Ghoul, M. Enzymatic acylation of flavonoids. Process Biochem. 2006, 41, 2237-2251.

24. Magrone, P.; Cavallo, F.; Panzeri, W.; Passarella, D.; Riva, S. Exploiting enzymatic regioselectivity: A facile methodology for the synthesis of polyhydroxylated hybrid compounds. Org. Biomol. Chem. 2010, 8, 5583-5590.

25. Zatloukalova, M.; Enache, T.A.; Kren, V.; Ulrichova, J.; Vacek, J.; Oliveira-Brett, A.M. Effect of 3-O-galloyl substitution on the electrochemical oxidation of quercetin and silybin galloyl esters at glassy carbon electrode. Electroanalysis 2013, 25, 1621-1627.

26. Vacek, J.; Zatloukalova, M.; Desmier, T.; Nezhodova, V.; Hrbac, J.; Kubala, M.; Kren, V.; Ulrichova, J.; Trouillas, P. Antioxidant, metal-binding and DNA-damaging properties of flavonolignans: A joint experimental and computational highlight based on 7-O-galloylsilybin. Chem. Biol. Interact. 2013, 205, 173-180. 
27. Valentova, K.; Vidlar, A.; Zatloukalova, M.; Stuchlik, M.; Vacek, J.; Simanek, V.; Ulrichova, J. Biosafety and antioxidant effects of a beverage containing silymarin and arginine. A pilot, human intervention cross-over trial. Food Chem. Toxicol. 2013, 56, 178-183.

28. Wang, F.; Huang, K.X.; Yang, L.X.; Gong, J.X.; Tao, Q.F.; Li, H.B.; Zhao, Y.; Zeng, S.; $\mathrm{Wu}, \mathrm{X} . \mathrm{M}$.; Stockigt, J.; et al. Preparation of C-23 esterified silybin derivatives and evaluation of their lipid peroxidation inhibitory and DNA protective properties. Bioorg. Med. Chem. 2009, 17, 6380-6389.

29. Abourashed, E.A.; Mikell, J.R.; Khan, I.A. Bioconversion of silybin to phase I and II microbial metabolites with retained antioxidant activity. Bioorg. Med. Chem. 2012, 20, 2784-2788.

30. Zhu, L.F.; Xu, M.; Zhu, H.T.; Wang, D.; Yang, S.X.; Yang, C.R.; Zhang, Y.J. New flavan-3-ol dimer from green tea produced from camellia taliensis in the Ai-Lao Mountains of Southwest China. J. Agric. Food Chem. 2012, 60, 12170-12176.

31. Lu, Y.R.; Foo, L.Y. Antioxidant and radical scavenging activities of polyphenols from apple pomace. Food Chem. 2000, 68, 81-85.

32. Fujisawa, S.; Atsumi, T.; Ishihara, M.; Kadoma, Y. Cytotoxicity, ROS-generation activity and radical-scavenging activity of curcumin and related compounds. Anticancer Res. 2004, 24, 563-569.

33. Osman, A.M. Multiple pathways of the reaction of 2,2-diphenyl-1-picrylhydrazyl radical (DPPH center dot) with $(+)$-catechin: Evidence for the formation of a covalent adduct between DPPH center dot and the oxidized form of the polyphenol. Biochem. Bioph. Res. Commun. 2011, 412, 473-478.

34. Kawabata, J.; Okamoto, Y.; Kodama, A.; Makimoto, T.; Kasai, T. Oxidative dimers produced from protocatechuic and gallic esters in the DPPH radical scavenging reaction. J. Agric. Food Chem. 2002, 50, 5468-5471.

35. Yamaguchi, H.; Ishii, E.; Tashiro, K.; Miyazaki, S. Role of umbilical vein endothelial cells in hematopoiesis. Leukemia Lymphoma 1998, 31, 61-69.

36. Rasmussen, C.; Thomas-Virnig, C.; Allen-Hoffmann, B.L. Classical human epidermal keratinocyte cell culture. In Methods in Molecular Biology; Randell, S.H., Fulcher, M.L., Eds.; Humana Press: Clifton, NJ, USA, 2013; Volume 945, pp. 161-175.

37. Mersch-Sundermann, V.; Knasmuller, S.; Wu, X.-J.; Darroudi, F.; Kassie, F. Use of a human-derived liver cell line for the detection of cytoprotective, antigenotoxic and cogenotoxic agents. Toxicology 2004, 198, 329-340.

38. Pham, A.; Bortolazzo, A.; White, J.B. Rapid dimerization of quercetin through an oxidative mechanism in the presence of serum albumin decreases its ability to induce cytotoxicity in MDA-MB-231 cells. Biochem. Bioph. Res. Commun. 2012, 427, 415-420.

39. Figueiredo, P.; Elhabiri, M.; Toki, K.; Saito, N.; Dangles, O.; Brouillard, R. New aspects of anthocyanin complexation. Intramolecular copigmentation as a means for colour loss? Phytochemistry 1996, 41, 301-308.

40. Di Meo, F.; Garcia, J.C.S.; Dangles, O.; Trouillas, P. Highlights on anthocyanin pigmentation and copigmentation: A matter of flavonoid $\pi$-stacking complexation to be described by dft-d. $J$. Chem. Theory Comput. 2012, 8, 2034-2043. 
41. Nave, F.; Bras, N.F.; Cruz, L.; Teixeira, N.; Mateus, N.; Ramos, M.J.; di Meo, F.; Trouillas, P.; Dangles, O.; de Freitas, V. Influence of a flavan-3-ol substituent on the affinity of anthocyanins (pigments) toward vinylcatechin dimers and proanthocyanidins (copigments). J. Phys. Chem. B 2012, 116, 14089-14099.

42. Velu, S.S.; di Meo, F.; Trouillas, P.; Sancho-Garcia, J.C.; Weber, J.F. Regio- and stereocontrolled synthesis of oligostilbenoids: Theoretical highlights at the supramolecular level. J. Nat. Prod. 2013, 76, 538-546.

43. Gazak, R.; Marhol, P.; Purchartova, K.; Monti, D.; Biedermann, D.; Riva, S.; Cvak, L.; Kren, V. Large-scale separation of silybin diastereoisomers using lipases. Process Biochem. 2010, 45, 1657-1663.

44. Zatloukalova, M.; Orolinova, E.; Kubala, M.; Hrbac, J.; Vacek, J. Electrochemical determination of transmembrane protein $\mathrm{Na}^{+} / \mathrm{K}^{+}$-ATPase and its cytoplasmic loop C45. Electroanalysis 2012, $24,1758-1765$.

45. Joyeux, M.; Mortier, F.; Fleurentin, J. Screening of antiradical, antilipoperoxidant and hepatoprotective effects of 9 plant-extracts used in caribbean folk medicine. Phytother. Res. 1995, 9, 228-230.

46. Siekevitz, P.; Sidney, P.C.; Nathan, O.K. Preparation of microsomes and submicrosomal fractions: Mammalian. In Methods in Enzymology; Academic Press: Waltham, MA, USA, 1962; Volume 5, pp. 61-68.

47. Bradford, M.M. A rapid and sensitive method for the quantitation of microgram quantities of protein utilizing the principle of protein-dye binding. Anal. Biochem. 1976, 72, 248-54.

48. Council for International Organizations of Medical Sciences. International ethical guidelines for biomedical research involving human subjects. Bull. Med. Ethics 2002, 182, 17-23.

49. Gazak, R.; Valentova, K.; Fuksova, K.; Marhol, P.; Kuzma, M.; Medina, M.A.; Oborna, I.; Ulrichova, J.; Kren, V. Synthesis and antiangiogenic activity of new silybin galloyl esters. J. Med. Chem. 2011, 54, 7397-7407.

50. Atanasova, G.; Jans, R.; Zhelev, N.; Mitev, V.; Poumay, Y. Effects of the cyclin-dependent kinase inhibitor CYC202 (R-roscovitine) on the physiology of cultured human keratinocytes. Biochem. Pharmacol. 2005, 70, 824-836.

Sample Availability: Samples of the new compounds are available in miligram amounts from the authors at the Institute of Microbiology, Prague, Czech Republic.

(C) 2014 by the authors; licensee MDPI, Basel, Switzerland. This article is an open access article distributed under the terms and conditions of the Creative Commons Attribution license (http://creativecommons.org/licenses/by/3.0/). 